\title{
A GIFT FOR A PUBLIC SERVANT - A MANIFESTATION OF RESPECT, REWARD OR A MEANS OF UNLAWFUL INFLUENCE
}

\author{
Tetiana Kolomoets ${ }^{1}$, Natalia Verlos ${ }^{2}$, Yuliia Pyrozhkova ${ }^{3}$ \\ Zaporizhzhia National University, Ukraine
}

\begin{abstract}
The article, based on analysis of scientific works and legislation of different countries, singles out problematic issues of legal regulation of relations connected with the reception of gifts by public servants. It is substantiated that in modern conditions a gift, unfortunately, can be used not only as a manifestation of respect and gratitude but also an unreasonable enrichment of public servant and unlawful influence on him, his official activity. Fragmentation, contradiction in the content of the "gift" legislation, its saturation with its evaluative and generalizing provisions predetermines the existence of "grey" zones in the legal basis of the use of a gift resource for public servants. Analysing existing prohibitive, restrictive, permissive models of "gift relations in the public service", the expediency of introducing an absolute prohibition on gifts for public servants is justified. It is proposed to provide exceptions for "ordinary" gifts, "official" gifts, and gifts on the occasion of special personal events, with the definition of limits of allowed behaviour. The mandatory declaration of all gifts received by a public servant, indicating its sources, seems expedient. The normative definition of a "gift" is proposed to be fixed in a special anticorruption legislative act, focusing on its disinterested symbolic, non-systematic nature, the legitimacy of acts of the servant as the basis for the gift, and the absence of any arrangements for its provision between the public servant and the "donor of a gift." As a result, it eliminates its mistaken association with unlawful benefits, public servant's labour compensation, incentive, and indemnity payments. Taking into account the specifics of "official" ("business") gifts, detailed regulation of rules of conduct with them is proposed, including the possibility of their redemption, with the priority of realization and protection of public interest. The necessity of unification of legal principles of regulation of "gift relations in the public service" and coordination of provisions of anti-corruption (in the part of special prohibitions and declaration as a means of preventing conflicts of interest in the public service), tax (in terms of declaration of incomes and determination of the legality of their sources), and tort (liability for breach of established regulations) legislation is grounded. It is considered appropriate to form uniform legal standards for the implementation of "gift policy in the public service."
\end{abstract}

Key words: reward, prohibition, corruption, restriction, reception, gift, gift relations, public servant, public service, rules, unlawful acts, donor, conflict of interest.

JEL Classification: D73, H83, D74

\section{Introduction}

In the search for the best means of preventing and counteracting corruption offenses and corruptionrelated offenses, an in-depth analysis of the traditional means of prevention of the conflict of interest in the professional activities of public servants is important. Among the latter, a prominent place belongs to special restrictions or special prohibitions on the reception of gifts by the abovementioned persons (special subjects, taking into account the peculiarity of their legal interest and sphere of professional activity) as these gifts are usually used in conjunction with the declaration of these persons of their income and expenditures (including gifts as a part of the first one). The fragmentation of the statutory regulation of relations related to the implementation of the state's "gift policy" with regard to public servants, to the dispersion of the relevant principles in numerous legal acts that are diverse in terms of legal force, oversaturated by appraisal concepts, to the simultaneous absence of clear criteria for determining models of lawful and unlawful behaviour, including concerning the declarations for gifts, predetermines

\footnotetext{
Corresponding author:

${ }^{1}$ Faculty of Law, Zaporizhzhia National University.

E-mail: t deputy@ukr.net

${ }^{2}$ Department of Constitutional and Labour Law, Zaporizhzhia National University.

E-mail: verlos79@gmail.com

${ }^{3}$ Department of Criminal Law and Justice, Zaporizhzhia National University.

E-mail: pyrozhkovaznu@gmail.com
} 
the prevalence of violations of special restrictions by public servants, in particular, with the avoidance of legal liability. Elimination of such a state of affairs should play the role of the priority task of the current regulatory and law-enforcement activity of any state, taking into account the positive existing experience, approved by time and practice, and the formation of uniform legal standards of "gift relations in the public service." The issue of regulation of "gift relations in the public service" attracted the attention of a considerable number of legal scholars, representing various branch specialties. This is quite justified, given that in different countries, corresponding relations are subject to the regulation of various branches (administrative, criminal, etc.). Some aspects of legal regulation of "gift relations in the public sphere," definition of permitted, prohibited behaviour models were covered in works of A. Hafurova, D. Paihin, V. Vasyliev, S. Zymnieva, H. Chumakova, S. Bonsing, L. Langsted, I. Bykieiev, K. Berdnikova, V. Nastiuk, V. Bielievtsova, O. Klok, O. Dudorov, M. Khavroniuk, and others, which were used when writing this paper. At the same time, despite all the diversity and plurality of sources, by this time, there are no complex works with a comparative legal analysis of legal provisions, the practice of law enforcement, proposals for the development of common legal standards of "gift policy in the public service", which determines the relevance and significance of in-depth scientific thematic study.

The purpose of the paper lies in distinguishing the problem issues of "gift policy in the public sphere" on the basis of analysis of various sources, thus identifying the real resource of the gift and formulating specific proposals on the legal regulation of relations of gifts' reception by public servants, their declaration, eliminating the preconditions for conflicts of interest in the public service.

\section{Key research findings}

In order to find out what is really a gift for a public servant, one should focus first of all on what should be considered a gift. The analysis of the legislation of different countries, scientific works of representatives of various scientific schools allows suggesting that the legislator in different countries clearly delineates a gift in the aspect of private law regulation (contractual relations, including with the participation of public servants, when the latter acquire the status of ordinary subjects of contractual relations, without emphasis on the specifics of their legal status, the peculiarity of their professional activity) and special gift relations in the aspect of anti-corruption regulation (with the emphasis on attaching a gift to the special status of a public servant, to his professional activities, oriented towards satisfying public interests). Emphasizing "special gift relations" associated with public service, the legislator fixes the definition of a gift. Thus, in Ukraine, a gift is considered to be a "cash or other property, advantages, benefits, services, intangible assets that are provided (received) free of charge or at a price below the minimum market" (Article 1 of the Law of Ukraine "On Prevention of Corruption"). At the same time, at the level of by-laws, the official legislative definition may be elaborated. Thus, in particular, the Rules of Ethical Conduct and Corruption Prevention in the Bodies of the State Fiscal Service, approved by the Order of the SFS on 01.12.2017, No.979, stipulate that the gift should also be considered "free education, transportation, accommodation, and food, both those provided directly, and through the purchase of tickets, subscriptions, or reimbursement after payment was made". In the USA, a gift is considered as a "monetary remuneration, refrain from any actions or other actions, items that may have a monetary expression" (Standards of Ethical Conduct for Employees of the Executive Branch, approved by the Regulation of the United States Office of Government Ethics). The same document clarifies that gifts may be expressed "... in the natural form, or in a different form (reimbursement of expenses, purchase of tickets, etc.)". Canada's law provides that a gift for a public servant can be considered any item, service, action, etc., if it can be expressed in monetary form (Bikeev, 2013).

Analysing the proposed definitions, it can be argued that, despite the variety of external forms of the expression of a gift, its main features nevertheless are: a) the relationship with a special subject - the person to whom the gift is offered, as well as: b) its free-ofcharge basis (or sometimes concealed minimum cost), which makes it impossible for the presentee to perform a similar action in relation to the person who proposes (provides) the gift; c) the legitimacy of the presentee's actions as a basis for the emergence of gift relations. Several clarifications should be made. Undoubtedly, the spontaneity of actions of the person who provides the gift ("gift donor"), the absence of any prior agreements between the subjects of gift relations is a specific feature that is inherent in relations with the so-called "special gift," "gift relations in the public service," and this has repeatedly drawn attention of legal scholars. The absence of a preliminary arrangement is related to the lack of the obligation of the gift's recipient to take any action in relation to the presenter (gift donor). It is the selfless nature of "gift relations in the public sphere" that is their specific feature. It is entirely possible to support the position of I. Bykieiev that the gift in this aspect should be regarded as "a thing, a material object, which the donor, on his own terms and for free, presents in order to provide pleasure or the benefit to the recipient of a gift ... At the expense of the gift the donor initiates the legal relations, sends a reminder of himself" (Bikeev, 2013). Giving a gift, the donor does not expect from a public servant any reciprocal action, a reverse adequate response. That is why it is quite legitimate to regulate at the legislative level the prohibition for public servants 
to receive gifts directly related to their professional activities in the realization and protection of public interests, as well as gifts from subordinates, which may predetermine a certain "need for a reverse adequate response," which is a kind of encroachment on the "purity of official activity," the impartiality and fairness of the latter. Such a prohibitive model of gift relations is enshrined in the laws of many states. For example, in the USA, Ukraine, Germany, Denmark, Finland, China, the Netherlands, and other countries, it is prohibited to receive gifts that are directly related to professional activities and from subordinates. For violation of the relevant provisions, criminal liability is provided. In Poland, such prohibitions apply to persons assigned to political positions, and officials in elected positions in local self-government bodies, and in Hungary members of parliament (Manuel Villoria, Staffan Synnerström, János Bertok, 2010, p. 20). In Moldova, the ban on the receipt of gifts extends to civil servants for the entire period of their official duties (Gafurova, 2015), and the Prime Minister of Latvia is able to receive all gifts given to him during the exercise of his powers only after leaving the post and only in terms of their redemption (Gafurova, 2015). Such a prohibition seems to be quite justified, given that the gift to a public servant, as a rule, is not granted "for no special reason." The practice of analysing "gift relations" suggests that "nobody gives public servants, especially regarding their business activities, gifts for no particular reason" (Zimneva, Chumakova, 2015). They are provided before or after the satisfaction of certain "interests," although in practice these facts are difficult to prove. However, "gift relations" are preceded by or are the result of relations involving the exercise by a public servant of his or her powers regarding elements of the legal status of the donor or persons associated with him. It is these gifts that pose a threat to the "purity of service" and should be prohibited for any public servants.

However, in some countries, "gift giving relations" in the public service are legally enshrined, although there are few such examples. Thus, in particular, in Japan, exchanging gifts between public servants ("okaeshi") (translated from Japanese - "return") is foreseen. Upon receiving a gift, a public servant is obliged to give the donor ("actually return") a gift of approximately the same value (Bikeev, 2013). Without denying the specifics of such a model of "gift relations in the public service" and its admissibility for Japan, nevertheless, it should be assumed that there are a large number of problems related to its practical implementation and, therefore, the expediency for borrowing by other countries.

It is also necessary to focus on the legitimacy of actions of a public servant as the basis for the emergence of "gift relations in the public service." It is the lawful nature of acts (actions or inaction) of public servants that prompts the donor, and in this aspect, the gift should be distinguished as a reaction (before or after) to lawful acts and unlawful benefits as a reaction to unlawful acts of a public servant. The gift is associated with "positive" and unlawful benefit - with the "negative" acts of a public servant. That is why the gift can be regarded as a manifestation of "respect, gratitude, recognition of acts of a public servant" (Zimneva, Chumakova, 2015). At the same time, it should not be considered as a promotion in civil service law, which is directly related to "public approvals, the recognition of personal merits, successful and faithful fulfilment by the person of his or her official duties, the results achieved with the provision of a person with material, moral, status, and other benefits, values, guarantees, privileges, etc." (Armash, Berlach, Bolokan at al., 2017). It is not worth to equate the gift with the payment for labour as a whole, taking into account the specific features of the latter, as well as a compensation payment, which may also have a one-time nature, but significantly different grounds, procedure, subjects of provision. In the legislation of some foreign countries, a clear distinction is made between remuneration and a gift. Thus, the Law of the Russian Federation on 25.12.2008 "On Corruption Counteraction" provides for the prohibition to receive remuneration (loans, monetary and other remuneration, services, payment for entertainment, rest, transport expenses) and gifts not stipulated by the legislation in connection with the performance of official (job) duties (Chernogor, Zaloilo, Ivaniuk, 2017).

Interesting is the ratio of a gift with a present, souvenir, the mention of which can be found in the legislation of many foreign countries, as well as in the works of legal scholars. For example, the Code of Conduct for Senior Civil Servants in the Brazilian Federal Executive Branch (NFA Code) - Certificate of Intent No.37 on 18.08.2000 and Presidential Decree on 21.08.2000 - prohibits any remuneration and gifts (Article 9), travels and signs of hospitality (Article 7) (Vasileva, 2015). The explanation of the Ministry of Justice of Ukraine on 28.07.2011 at one time stipulated that "the permitted gift may be ... manifestations of hospitality, namely: invitation for coffee or dinner on a modest scale ... for establishing business relations and strengthening working relations" (Kolomoiets T.O. Restrictions on the reception of gifts by persons authorized to perform functions of the state or local self-government under the legislation of Ukraine: scientific and practical commentary, 2018). In Great Britain, members of parliament or their spouse or partner are required to declare any gift, service, remuneration or hospitality worth more than 1 percent of parliamentary salary if in one way or another it is directly related to membership in a parliamentary chamber (Manuel Villoria, Staffan Synnerström, János Bertok, 2010). At the same time, it is allowed to receive "notebooks, calendars, and other stationery products of "insignificant" value with the logos of the producing companies," which allows them to be considered as 
advertising products. In the Republic of Belarus, it is allowed to receive "... souvenirs during official events" (Kolomoiets T.O. Gifts for public servants in Ukraine: prohibition, restriction or permission as an optimal model of legal regulation, 2018). The Code of Conduct for EU Commissioners in section 1.11 establishes a prohibition on signs of hospitality, with the exception of those provided during official diplomatic events and as signs of courtesy (though, again, the appraisal concept is used). The participation of a commissioner in any event on an invitation should not be considered as hospitality (Sten Bonsing, Lars Langsted, 2013). In Brazil, in the Code of Conduct for Senior Civil Servants in the Federal Executive Branch, bans on gifts, rewards, signs of hospitality and services are fixed in general in separate articles, with the listing of their possible external forms of manifestation, though without official definitions. In this regard, in the case of gifts ("brindes"), in the Resolution of the Commission on Public Ethics CEP No. 3/00/2000), the NFA Code stipulates that they are provided "as a sign of courtesy, a marketing tool, on the occasion of events of historical or cultural character" (Vasileva V.M., 2015, p. 176-177). A souvenir (from French souvenir, Latin subvenio "come") is traditionally considered as a kind of gift in memory (a certain remarkable event, a memorable date, achievements in sports, science, culture, national or local specifics, etc.), a present (from Old Slavonic гість "guest") - as a thing which a person who "enters the house, transfers to the owner, to get "good food" (Pryma, 2016). Consequently, a souvenir, a present, and a gift form a single thematic conceptual series, while closely related to "the subjective judgment of a person based on the historically established customs, rituals, traditions, tastes, historically predetermined guidelines of the public consciousness concerning benevolent attitude towards the person, moral and ethical norms of communication" (Kolomoiets T.O. Restrictions on the reception of gifts by persons authorized to perform functions of the state or local self-government under the legislation of Ukraine: scientific and practical commentary, 2018). They are associated with symbolism, insignificant value, small size, and unsystematic provision (reception). At the same time, taking into account the specifics of the subject of obtaining gifts and his or her professional activity, it is impossible to underestimate the possibility of the gift's influence on the "purity" of the relevant activity. Especially since the legislation is over-saturated with such "grey zones" (Sten Bonsing, Lars Langsted, 2013), which create the basis for the diversified use of the gift resource for a public servant.

Unfortunately, the absolute prohibition on the reception of gifts by public servants is not provided for in the legislation of all states. The prevailing is the so-called "mixed" model of "gift relations in the public service," which, along with the general prohibition, also contains special restrictions (model of behaviour with certain limits) for the receipt of gifts by the specified persons, which creates certain problems in practice. Due to the fact that the criteria for determining the limits of permissible conduct are not clear in the majority and the provisions that determine these limits are oversaturated by evaluative and generalized provisions, in practice there is a variation in the discretion of the subject of interpretation in the observance of special restrictions, control over the latter, including in relation to the simultaneous use of other means to prevent conflicts of interest in the professional activities of a public servant.

For example, the Ukrainian legislation provides that the abovementioned persons can receive gifts, if they are not prohibited and also comply with generally accepted notions of hospitality, correspond to the value (no more than one living wage for the able-bodied person on the day of receiving the gift), source (from the same person or group of individuals), and periodic criteria (once or several times during the year from one source) (On Corruption Prevention: Law of Ukraine on 14.10.2014). The cost boundaries of "gift relations in the public service" are also characteristic of the legislation of foreign countries. For example, in France, the cost limit of a gift is equal to 35 euros; in Great Britain, the cost of a gift to a member of the government or to a designated person cannot exceed 140 pounds sterling. A person can keep a gift of greater value if he or she pays to the state treasury a difference between its real value and allowed (Bikeev, 2013). In this case, parliamentarians and civil servants cannot accept any gifts (Manuel Villoria, Staffan Synnerström, János Bertok, 2010). In Singapore, ministers and their family members can take gifts of up to 50 Singapore dollars; more expensive gifts can be redeemed through an auction (Bikeev, 2013). In the Republic of Belarus, public servants can accept gifts during official protocol events, if their value does not exceed "five basic values" (Kolomoiets T.O. Gifts for public servants in Ukraine: prohibition, restriction or permission as an optimal model of legal regulation, 2018), in the Russian Federation, the cost of a gift should not exceed three thousand roubles, and in the USA - twenty dollars per donor in each particular case, however, the legislation contains clarification that the total cost of gifts from one source during the year (hence, emphasis on all the features of the allowed gift) cannot exceed fifty dollars (however, these limits do not apply at all to cash money) (Standards of Ethical Conduct for Employees of the Executive Branch: Regulation of the United States Office of Government Ethics). Somewhat different are the cost limits for gifts for senators and congressmen - two hundred and fifty and three hundred US dollars respectively, and in Brazil, the value limit for any gift cannot exceed one hundred reals (Vasileva, 2015).

Despite some certainty of the criteria of the value sign of the gift, unfortunately, it is impossible to acknowledge such a practice of rule-making as positive. 
This is determined by the fact that the legislator does not adhere to the unity of legal principles of "gift relations in the public service." By offering in one regulatory legal act criteria for determining the maximum cost of a gift granted to a public servant, the legislator in another act (and sometimes in the same) offers an approximate (and sometimes exhaustive) list of those objects, services, benefits, which in any case are allowed as a gift. For example, the Regulation of the United States Office of Government Ethics includes the following: soft drinks, light snacks served separately from the main meal, greeting cards, honour badges, memorable gifts for the presentation of the institution, awards for the winners of the competition, etc. (Standards of Ethical Conduct for Employees of the Executive Branch: Regulation of the United States Office of Government Ethics). I. Bykieiev, analysing the relevant question, forms a list of those items that are usually considered as allowed (at the level of sub-legal regulation) of gifts: "books, booklets, albums, some art products, flowers, candies, products of the donor himself or things, which are brought from another territory ... sometimes items of home appliances that cause associations" (Bikeev, 2013).

However, some countries have chosen a slightly different vector of legislative regulation of "gift relations in the public service," generally avoiding the valued criterion of the allowed gift. For example, in China, at the legislative level, a list of prohibited items to receive as a gift is secured. These are virtually all items, with the exception of books. Violation of established prohibitions is considered as a crime, which provides for criminal liability in the form of a death penalty.

In addition, cases of contradictory and conflicting legal principles governing the regulation of "gift relations in the public service" are uncommon, when the legislator actually creates the preconditions for the possibility of receiving gifts by public servants without observing the requirements regarding their value, periodicity, sources of income. Thus, the basis for the possible use of the gift resource as a measure of unlawful influence on the "purity" of the public service, as well as unjust enrichment of the public servant, is created. For example, in the Russian Federation there is a collision of the provisions of three statutory legal acts, namely: the Civil Code, which, along with the general prohibition to receive gifts by persons authorized to perform functions of the state or local self-government, at the same time allows the person to receive "ordinary gifts," the value of which does not exceed three thousand roubles, the Criminal Code, which provides for liability, but does not specify the minimum amount of wrongful remuneration, as well as a special anti-corruption law, which establishes an absolute prohibition on receiving gifts and other remuneration by public servants. It is interesting to note the experience of Denmark, the legal position of its supreme court in relation to the conflict of provisions regulating the principles of "gift relations in the public service," as well as enshrined in various statutory legal acts (namely, the Criminal Code and a special anti-corruption law) is that there is the "limit of tolerance of violations," which can be equal to $40 \%$ of the cost of the allowed gift. Accordingly, a public servant who has received a gift, which value exceeds the cost of a permitted (for example, jubilee) gift by $40 \%$, should not be criminally liable (Sten Bonsing, Lars Langsted, 2013).

Along with the clear criterion for determining the value limit of a gift for a public servant, the law of countries can simultaneously contain other provisions, namely: "minimal gifts," "traditionally small gifts," "gifts at very low cost," "socially acceptable gifts," "small gifts for special events," etc(Sten Bonsing, Lars Langsted, 2013). Certain questions also arise in relation to monitoring compliance with the law in determining the periodicity of accepting gifts by the person during the year, thus eliminating "systematic gift relations in the public service," which significantly threaten the impartiality and objectivity of the professional activities of a public servant. As already noted, in the legislation of many countries, gift relations are regulated with an emphasis on the frequency of their occurrence during the year and the total value of gifts for the whole year, obtained from one source. For example, in Ukraine, a public servant can receive gifts for a year, the aggregate value of which does not exceed the maximum limit, or one time, or several times from one source. Similar provisions are enshrined in the laws of the USA, Brazil, Great Britain, and other countries. In order to ensure control over the observance of these provisions of the legislation, it is fully justified to introduce a unified registration of gifts received, with the indication of its sources ("gift donor") and the date of receipt. Accepting that the practical implementation of the said proposal is connected with additional formal procedures, time expenditures, etc., as an alternative, it is possible to offer mandatory declaration by all public servants of all gifts received during the year, indicating the sources ("donors") of their provision (this practice already exists in Latvia, Sweden, and Finland (On the issue of attitude to gifts within the system of fighting corruption). The contradictory nature of provisions, the oversaturation of legislation with the evaluative and general provisions on determining the value limits of gifts for public servants, as already noted, predetermines the prevalence of the practice of receiving gifts, which "unjustified" nature (namely, this term is basic in relation to the definition of grounds for accepting gifts by the relevant subjects) is difficult to prove. That is why the prohibitive model of "gift relations in the public service" seems more appropriate since it clearly defines the impossibility of any acts related to gifts (fixes "taboo" in relation to any gifts for any public servants), eliminates grounds for the variability of the interpretation of statutory provisions, promotes the unification of enforcement, simplifies the 
control and the possibility of bringing the perpetrators to legal liability for violation of the established prescriptions. This model will eliminate the grounds for the so-called "indirect gifts" (which are actually addressed to a public servant but are provided to their relatives); they are also referred to as "gifts through other persons.” Introducing, along with such a prohibition, the duty to declare all gifts received, indicating the sources of their receipt, as by public servants so by their close persons, can actually strengthen the principles of transparency of "gift relations in the public service," contributing to the "purity" of the public service, eliminating the preconditions for using the gift as a means of unlawful influence on a person.

Public officials, like other individuals, can also receive gifts that are not directly related to official activity, including from their close ones. At the same time, such gifts are not limited by their value, periodicity, and sources. This practice is widespread in all states, which is fully justified (so-called "normal gifts," "ordinary gifts," "private gifts" etc.), and provides for the mandatory declaration of gifts received since the latter is income received. It is considered expedient to introduce the indication of the source of gift's receipt, along with the obligation to declare the corresponding gift by a public servant. In turn, in case of doubts as to the legality of obtaining such a gift, it allows asking certain questions to the "gift donor." It is important to ensure the unification of the legal basis for declaring gifts received by public servants by extending the obligation to declare to all (and not only those whose value exceeds the limits) gifts, since all this is a person's income, although, for example, in the United Kingdom, Members of the Parliament must declare only gifts worth more than one percent of their salary, and members of the German parliament - five thousand euros, while their colleagues from France must declare all the gifts regardless of their value (Manuel Villoria, Staffan Synnerström, János Bertok, 2010). The regulation of such a proposal will eliminate the practice of the existence of "grey zones" in the legislation on the declaration of gifts, when the maximum price limit of a gift allowed for a public servant significantly (several-fold) differs from the minimum value limit of the gift that is to be declared by this person (for example, in Ukraine the first position is equal to one (two) living wage for an able-bodied person, and the second one - to five, and hence there is a question regarding gifts that on a cost basis are between these two positions). Since a gift for a public servant is an income, including generally acknowledged bonuses, prizes, privileges, winnings in a lottery, etc., in order to eliminate any doubts as to the "purity" of his or her business activities, all gifts accepted should be declared.

It is appropriate to ask whether there maybe exceptions to the general prohibitive model of "gift relations in the public service"? Yes, besides the so-called "private gifts" ("normal gifts," "ordinary gifts," that is, gifts from close persons, with the confirmation of the last legal sources of funds for their provision), public servants may well receive gifts "on the occasion of certain special events." For example, in the USA, the law provides that public servants can accept, including from their colleagues, subordinates, gifts on the occasion of "special events of personal nature - marriage, birth, retirement, transfer to another job, etc." ( $\$ 2635.304$ of the Regulation of the United States Office of Government Ethics). In Ukraine, the provisions of such content are regulated with the possibility of accepting gifts by public servants, including from subordinates, concerning special events of personal or traditional importance, public or professional holidays (paragraph 25 of the Rules of Ethical Conduct and Corruption Prevention in the Bodies of the State Fiscal Service, approved by the Order of the SFS on 01.12.2017, No. 979). However, such exceptions should stipulate statutory value limits of the gift, the exclusiveness of the character of the gift, and the obligatory declaration by the public servant of all gifts received since this is also his income.

It is also quite right to question the expediency of extending the prohibition on the reception of "business" ("official") gifts or their declaration. Among all the diversity of gifts, the main place is occupied by the so-called "business," they are also called "official" gifts. These are gifts, accepted by public servants as representatives of the state, territorial community, state, communal enterprises, institutions, organizations, in the performance of their duties during official events. The specificity of such gifts also determines the peculiarity of the statutory regulation of principles of accepting them (a separate legal act, a separate section of a special legal act, etc.). It is unlikely that it is expedient to foresee a ban on their receipt, taking into account the specifics of these gifts, which, although directly and specifically provided to a public servant, are the property of the state, the community, etc. At the same time, the rules for handling such gifts require a detailed definition (transmission terms, the procedure for issuing the transfer, storage, destruction, etc.), as well as the responsibility for their violation. Given that these gifts are not revenue for public servants, it is also inappropriate to introduce a duty to declare them. However, it is quite possible to regulate the issue of the redemption of a given gift by a public servant (subject to a certain procedure), unless this is detrimental to the public interest. This practice exists, for example, in Latvia, Singapore, and other countries. Given the weighed detailed regulatory regulation of such relationships, it is quite possible to reduce the costs of the state, the community, etc. for the storage of the corresponding gifts and simultaneous provision of additional filling of the corresponding budgets. In order to eliminate the preconditions for considering "business" ("official") gifts as a means of undue influence on public servants, their unjustified enrichment, it is necessary to ensure 
officiality, transparency (first of all with regard to the source of receipt) of "gift relations," thereby eliminating the privacy manifestation (personalization of the gift, its encouragement, financing, including in any form, size, on the part of private persons, etc.). A well-defined statutory regulation of this issue should contribute to this.

\section{Conclusions}

The current state of legal regulation of "gift relations in the public service" predetermines the presence of a significant number of problematic issues that do not allow, unfortunately, on the one hand, to fully use the gift resource as a manifestation of respect, gratitude, recognition to a public servant and, on the other hand, create preconditions for considering it as an unwarranted reward of such a person and means of unlawful influence on him. The lack of unified legal standards for regulating the relevant "gift relations" leads to the dispersion of the consolidation of legal principles in various legal acts, the provisions of which differ not only in a fragmentary nature, as a consequence - many "grey zones," but also contradictory in nature. The collision of the content of the relevant acts, the saturation of the latest with valuation and generalized provisions, which creates preconditions for subjective discretion in the process of interpretation and enforcement, is rather widespread. The lack of a formulated thematic conceptual framework, as well as a systematic approach to the normative consolidation of the bases of using the resource of prohibitions and restrictions on the reception of gifts by public servants in the aspect of behavioural patterns, criteria for expressing the limits of the permitted cost together with the declaration of these gifts, results in widespread practice of obtaining unwarranted gifts by public servants, unlawful influence on the "purity" of their professional service activities, as well as the avoidance of legal liability by guilty persons. In order to eliminate this state of affairs, it is considered expedient: 1) statutory definition of a gift in a special anti-corruption legal act, with an emphasis on the legitimate nature of acts of a public servant as the basis for the possible provision of the gift, as well as the selfless symbolic, non-systemic nature of the gift itself and the spontaneity of the donor initiative ("donor of a gift"). Thus, providing a separation of gifts for a public servant from unlawful benefits, promotion, remuneration for labour (payment for labour), compensation payments. 2) to formalize the prohibitive model of "gift relations in the public service", removing the influence on the "cleanliness of the official activity" of the person. As exceptions to the general rule, provision should be made for: a) the reception of "private gifts" by public officials ("ordinary gifts," "normal gifts"), that is, gifts that are completely unrelated to his or her official activity, including from the relatives, with the obligatory indication of sources for gifts by the latter; b) accepting "official" ("business") gifts, which, although are issued by specific public servants in the course of their official activities during official events, are the property of the state, the community, etc. It is expedient to see a detailed statutory regulation of the rules of handling such gifts (including the possibility of their redemption), and the bases of legal liability for their violation; c) reception of gifts on the occasion of special personal events of a public servant, with the definition of an approximate list of such events, the allowed cost limits of the gift, the exceptional nature of the gift. 3) the normative consolidation of an obligatory declaration by all public servants of all received gifts, indicating their sources, as well as determining the principles of legal liability for non-compliance with these provisions. 4) unification of statutory principles of regulation of "gift relations in the public service" and hereby the harmonization of the provisions of anti-corruption legislation in the part of special prohibitions and declaration of incomes of public servants, tax legislation in relation to declaring incomes of public servants and "donors of gifts" for them, as well as tort law in part of determination of the principles of legal liability of the perpetrators for violation of the relevant legal requirements.

It is the practical implementation of the relevant proposals that will promote maximum transparency, certainty of "gift relations in the public service," use of the gift resource as a manifestation of respect, gratitude to the public servant, and elimination of any grounds for considering it as a means of unjustified enrichment of a public servant or unlawful influence on his or her official activity.

\section{References:}

Rules of Ethical Conduct and Corruption Prevention in the Bodies of the State Fiscal Service, approved by the Order of the SFS on 01.12.2017 № 979. URL: http://sfs.gov.ua/baneryi/protidiya-koruptsii/antikoruptsiynaprograma-dfs/291898.html

Standards of Ethical Conduct for Employees of the Executive Branch: Regulation of the United States Office of Government Ethics / The Code of Federal Regulations. № 5. Part 2635. URL: https: / /www.google.com/url?sa=t\&rct=j\&q=\&esrc=s\&source=web\&cd=2\&cad=rja\&uact=8\&ved=0ahUKE wibtKzXkunZAhWJC8AKHc3JCw4QFggxMAE\&url=https\%3A\%2F\%2Fwww.oge.gov\%2Fweb\%2Foge.nsf\%2F 0\%2F85BC960EDCDC284885257EA6006557FA\%2F\%24FILE\%2F4e6d8560a22d479885e24b6699d71adc1. doc\&usg=AOvVaw2xpvqE2yvxmrsNJf18LLMO

Bikeev I.I. (2013). Issues of delimitation of a bribe from a gift in Russia and abroad: practice and trends. Actual Problems of Economics and Law. № 1. P. 245-249. 
Ethics of the civil service: prevention of conflict of interests and requirements to legislation / Manuel Villoria, Staffan Synnerström, János Bertok; [translated from English by I. Chupryn]. K.: Centre for Adaptation of the Civil Service to the standards of the European Union, 2010, 104 p.

Gafurova A.Kh. (2015). To the issue of gifting luxury goods as a volatile component of the development stages of society. Features of accepting gifts by civil servants. Vestnik of Kostroma State University. Legal sciences. № 6. P. 169-172.

Svetlana Zimneva, Anna Chumakova. (2015). Legal Regulation of Civil Servants in Russia and Germany Receiving Gifts. Russian Law Journal. Volume III. Issue 3. P. 142-151.

Encouragement in civil service law: study guide / N.O. Armash, Yu.A. Berlach, I.V. Bolokan [at al.]; under the general editorship of T.O. Kolomoiets, V.K. Kolpakov. - K.: In Jure, 2017. 360 p.

Chernogor N.N., Zaloilo M.V., Ivaniuk O.A. (2017). The role of ethical and moral standards in ensuring compliance with prohibitions, restrictions, and requirements established to counter corruption. Journal of Russian Law. № 9. P. 130-141.

Vasileva V.M. (2015). Regulation of conflict of interest in public service: the Brazilian experience (Part 2). Public Administration Issues. Issue 3. P. 165-190.

Kolomoiets T.O. (2018). Restrictions on the reception of gifts by persons authorized to perform functions of the state or local self-government under the legislation of Ukraine: scientific and practical commentary. Zaporizhzhia: Publishing House "Helvetica", 40 p.

Kolomoiets T.O. (2018). Gifts for public servants in Ukraine: prohibition, restriction or permission as an optimal model of legal regulation. Juridical Scientific and Electronic Journal. № 1. P. 92-96.

Sten Bonsing, Lars Langsted (2013). "Undue" Gifts for Public Employees: An Administrative and Criminal Law and Criminal Justice. № 21. P. 163-184.

Pryma V. (2016). Hospitality as an unconditional gift: to the problem statement. Culture and Art in the Modern World. Issue 17. P. 91-96.

On Corruption Prevention: Law of Ukraine on 14.10.2014. Gazette of the Verkhovna Rada of Ukraine. 2014. № 49. Art. 2505-6 (with subsequent amendments and additions).

On the issue of attitude to gifts within the system of fighting corruption. URL: http://e-notabene.ru/pr/ article_827.html 